\title{
Towards a theology of development in the Uniting Reformed Church in Southern Africa (URCSA) Embodying Article 4 of the Belhar Confession
}

\section{Jacques Beukes ${ }^{1}$ \& Mary-Anne Plaatjies van Huffel ${ }^{2}$}

\begin{abstract}
The Belhar Confession gained shape following the social injustices that resulted from the policy of apartheid. Whilst the former mission church's role during the apartheid regime was that of resistance, its role in a post-apartheid South African context was supposed to change to reconstruction and assistance. Given the current socioeconomic situation and injustices, the Belhar Confession is now more than ever relevant and should therefore be the basis and motivation for the church to serve and be involved in the fight against poverty in South Africa. The church is therefore challenged to not solely depend on welfare projects in their role as poverty combaters but to move beyond a charity mode towards a mode of development.

Keywords: Poverty; Belhar Confession; Article 4; Church; Development; Theology of Development; URCSA
\end{abstract}

\section{Introduction}

On 26 September 1986 the Dutch Reformed Mission Church ${ }^{3}$ (DRMC) in Synod at Belhar accepted the Belhar Confession ${ }^{4}$ as a public confession against the theological justification of apartheid. The Belhar Confession consists of five subsections,

1 Jacques Beukes is a lecturer in the department of Theology at Hugenote Kollege and research associate in the department Practical Theology and Missiology, Faculty of Theology, at the University of Stellenbosch. He can be contacted at jbeukes@hugenote.com.

2 Mary-Anne Plaatjies van Huffel is an associate professor in Church Polity and Church History in the department Systematical theology and Ecclesiology, Faculty of Theology, at the University of Stellenbosch. She can be contacted at mapvanhuffel@sun.ac.za.

3 In 1652 the Dutch formed a halfway station at the Cape (approximately halfway between the Netherlands and the Dutch East Indies) and introduced slavery by whites. Various foreign mission organisations started working in South Africa, which led to the formation of a number of denominations amongst those people who otherwise would have been excluded from the main churches, largely over issues of race. This process motivated the Dutch Reformed Church (DRC) in South Africa to start its own independent mission work. In 1857 the DRC synod decided to have separate services for coloured members. A separate church, namely the Dutch Reformed Mission Church (DRMC), was formed in 1881. See also Modise, L. 2013 and Thomson, D. 2002 for a detailed discussion on the establishment of the DRMC.

4 For content of and a historical background on the Belhar Confession see Naudé, P.J. 2010, Botha, J \& Naudé, P.J. 2010, Plaatjies Van Huffel, M.-A. 2013b: 329-345, Plaatjies Van Huffel, M.-A. 2013a: 185-203, Strauss, P.J. 2004: 96-121, Kritzinger, J.N.J. 2010: 209-231. 
which for citation purposes will be referred to as Articles. The first Article repeats and confirms the ancient Christian belief in the triune God, who establishes the Church. The following three ${ }^{5}$ Articles, namely Unity, Reconciliation and Justice, deal with the church and her role in the world. The fifth Article calls the church to do what is confessed, even if it means persecution (Naudé 2010:5). The Belhar Confession is a confession in which the Uniting Reformed Church in Southern Africa (URCSA) ${ }^{6}$ affirms her faith and in doing so also compels herself to being a leader in the continuous struggle for socio-economic justice in South Africa.

This affirmation of faith is Biblically justified and is evident in the Belhar Confession. However, two URCSA theologians and scholars of the Belhar Confession, Smit (2006b:299) and Tshaka (2005:262), in their various reflections on the meaning of the Belhar Confession made critical inquiries on the URCSA's involvement in South Africa: "What are the challenges that face the URCSA in South Africa in its current changed and changing context? Is the URCSA doing enough to deal with the realisation of issues such as unity, reconciliation and justice?" (Tshaka 2005:262) and also "What would this truly mean in our world, our societies, today - to be a church [that] embodies the claims and convictions of our own confession?" (Smit 2006b:299). This paper attempts to address these critical reflections by exhorting the URCSA that all modes of involvement in the South African socio-economic context should be motivated and determined from its Biblical, but also from its Belhar Confessional convictions and beliefs, as the URCSA is called to embody what she confesses.

This critical assessment is necessary as the need for a reformed confession such as the Belhar Confession arose from moral or ethical crises and challenges; on the other hand any form of status confessionis calls the church to praxis, embodiment and doing of the gospel as it is expressed in the confessional language (Smit 2006a:9). This is particularly in view of the latter embodiment and practice of the Belhar Confession which emphasises the need to convert a biblical-theological perspective of Article 4 to a theology of development. In doing so we will firstly define what is meant by a theology of development; secondly we will [very] briefly deliberate on Korten's generation theories; thirdly the church and development will be discussed; and finally this paper will be concluded with the conversion of a biblical-theological perspective of the Belhar Confession, but especially of Article 4, to a theology of development.

5 Articles two to four (Unity, Reconciliation and Justice) are also known as the three pillars of the Belhar Confession (cf. Botha, J. \& Naudé, P.J. 2010).

6 In 1994 the Uniting Reformed Church in Southern Africa (URCSA) was formed by the unification of the black Dutch Reformed Church in Africa (DRCA) and coloured Dutch Reformed Mission Church (DRMC). 


\section{Defining a theology of development}

A theology of development refers to a theological sub-field which came into existence in the sphere of the World Council of Churches and the ecumenical movement, motivated by a Christian desire to creatively and wholeheartedly be involved in seeking solutions to human, social and political problems in the contemporary world (Dunne 1969:i; Dickinson 1991; cf. Moltmann 1969:96; Swart 2010:209211; Gern 1999:441; Abrecht \& Land 1969; Rendtorff 1969 \& 1971; Alszeghy \& Flick 1971; and Myers 2011). Such motivation to get involved in development was not however confined to the ecumenical movement, but on a global level a focus on development, especially in the last two decades, has become a major focus in the evangelical movement and churches (Offutt 2012; Reynolds \& Offutt 2014; Samuel 1996), while development also grew as a field of interest in theological circles in South Africa after the end of apartheid (De Gruchy 2001; Swart 2008a; Swart 2010; Swart 2012; cf. Klaasen 2013).

A theology of development focuses on holistic people-centred development from a practical theological perspective. Any involvement of churches and Christians in development in this regard can be considered as an approach which is theologically motivated and therefore implies a theology of development (Myers 2011:47). A theology of development should be established in the declaration that God and humanity are linked because of the cross (Moltmann 1969:96). Swart (2010:211) explains that a theology of development is a theology that is at task to empower the church for an effective role in development, as the church's past motivation for involvement was based on the Christian principle of love and it was recognised as a fundamental point that the traditional Christian sources were in themselves insufficient to guide the churches towards an effective praxis in development. Swart (2010:212) confirms this by saying, "[that] at most, such a point of departure would lead to a simplistic mode of involvement defined by the notion of charity, an obedient response to Christ's law of love through which nothing more but some basic necessities of life could be met. Essentially therefore, an ecumenical 'theology of development' involved the quest for new social understanding in order to empower the churches for development praxis responsive to the life problems of the modern world." Consequently, this paper pleads for a rethinking, renewal and redirection of the URCSA's current charity mode of involvement.

A theology of development involves a theological, ecclesiastical, Christian, biblical and confessional basis and perspective. This should serve as motivation for Christian active involvement of churches, NGOs, CBOs, FBOs and Christians as agents of change in the socio-economic challenges of society. Church involvement in society implies God's restoration in this world which leads to both spiritual and physical transformation and change in the lives of individuals and communities. 
It is against this background of the aforementioned conceptualisation of a theology of development that David Korten's valuable contribution of the Generation strategic NGO intervention will be discussed as it might assist the URCSA in understanding her role in development.

\section{Korten's generation strategic NGO intervention approach}

Korten (1990) studied the strategies of development through NGOs critically and identified specific strategies to address the situation in poor countries or communities. He critically scrutinized the three traditional strategies of development and proposed a fourth strategy. The first three strategies focus on (i) Relief and welfare, (ii) Community development and (iii) Sustainable systems development. The fourth strategy suggested by Korten (1990:115-123) is people-centred development.

However, it is essential to highlight Korten's classification of development strategies in this section (see diagram 1 )

When talking about effective church praxis, the work of David Korten should be consulted because it influenced the conceptualisation of church involvement in development significantly. David Korten is an internationally renowned expert in the field of alternative development theories. His work has greatly influenced participants in the South African church development debate (Swart 2008a:122). It is not only relevant for the promotion of a people-centred development philosophy but especially for perspectives on different modes of involvement or "generations" of NGOs' strategic interventions to achieve the goals of a people-centred development paradigm. Korten's classification is to my mind directly relevant to the URCSA's context that faces the challenge of moving beyond customary welfare and project-mode intervention to a more sophisticated mode of development.

According to Korten (1990:115-118), the first generation strategy started with the relief work or charity to people affected by various disasters. The relief and welfare approach is a classic international voluntary action aimed to provide assistance to victims of wars and natural disasters. NGOs were particularly involved in direct delivery of services for relief needs such as food, health care and shelter. Later it was realised that this form of intervention only provided temporary relief. The result of this mode of intervention was that beneficiaries were plunged into a long-term dependence on NGOs. Speckman (2007:13-15) states that this assistance had the opposite outcome from what was intended.

It is against this background that the second generation approach emerged in the 1970s. This period is known as the era of small-scale self-sustaining local development. It is also often referred to as community development strategies. The secondgeneration approach was motivated by the realisation that relief and welfare activities were not sustainable, but rather created dependency which was inconsistent with the 


\begin{tabular}{|c|c|c|c|c|}
\hline & \multicolumn{4}{|c|}{ G E N E R A T I 0 N $\mathbf{N}$} \\
\hline Defining features & $\begin{array}{l}\text { Relief } \\
\text { and welfare }\end{array}$ & $\begin{array}{l}\text { Community } \\
\text { development }\end{array}$ & $\begin{array}{l}\text { Sustainable systems } \\
\text { development }\end{array}$ & $\begin{array}{l}\text { People's } \\
\text { movement }\end{array}$ \\
\hline Year of reference & $1940 \mathrm{~s}$ & 1960s & 1970s & $1980 \mathrm{~s}$ \\
\hline $\begin{array}{l}\text { Problem } \\
\text { definition }\end{array}$ & Shortage & Local inertia & $\begin{array}{l}\text { Institutional } \\
\text { and policy } \\
\text { constraints }\end{array}$ & $\begin{array}{l}\text { Inadequate } \\
\text { mobilizing } \\
\text { vision }\end{array}$ \\
\hline Time frame & Immediate & Project life & Ten to twenty years & Indefinite future \\
\hline Scope & Individual or family & $\begin{array}{l}\text { Neighborhood or } \\
\text { village }\end{array}$ & Region or nation & National or global \\
\hline Chief actors & NGOS & $\begin{array}{l}\text { NGO } \\
\text { plus community }\end{array}$ & $\begin{array}{l}\text { All relevant public } \\
\text { and private } \\
\text { institutions }\end{array}$ & $\begin{array}{l}\text { Loosely defined } \\
\text { networks of people } \\
\text { and organisations }\end{array}$ \\
\hline NGO role & Doer & Mobilizer & Catalyst & Activist/educator \\
\hline $\begin{array}{l}\text { Management } \\
\text { orientation }\end{array}$ & Logistics manager & $\begin{array}{l}\text { Project } \\
\text { management }\end{array}$ & $\begin{array}{l}\text { Strategic } \\
\text { management }\end{array}$ & $\begin{array}{c}\text { Coalescing and } \\
\text { energizing self } \\
\text { managing networks }\end{array}$ \\
\hline $\begin{array}{l}\text { Development } \\
\text { education }\end{array}$ & Starving children & $\begin{array}{l}\text { Community } \\
\text { self-help }\end{array}$ & $\begin{array}{l}\text { Constraining policies } \\
\text { and institutions }\end{array}$ & Spaceship earth \\
\hline
\end{tabular}

Diagram 1: Korten's generation strategic NGO intervention approach

values and objectives of the NGOs, namely to empower people in rural areas (Korten 1990:118). As such, the focus shifted from what the NGOs can do for the poor against what the poor could do for themselves. The NGOs then began to see community development as the answer to sustainable development. The idea was to educate the poor effectively and to provide, inter alia, small loans, thereby empowering them to be selfsufficient. It would be the purpose of development. The development worker becomes in this case a facilitator and encourager (Korten 1990:119). Similarly, this approach is not without criticism. Korten (1990:119) for example suggests that in practice many second generation interventions are still very sophisticated hidden "handouts". In other words, many of these second generation interventions give little more than lip service to self-reliance and in fact build long-term dependence on the NGOs. 
The aim of the third generation is to combat local inertia. Local inertia is maintained by structures that centralise the control of resources, which keeps essential services out of reach of the poor and maintains the system of corruption and exploitation. There is a need for a policy and institutional environment that facilitates it, rather than to limit sustainable and inclusive local development actions. Therefore, the third generation approach strives for changes in policies and institutions at local, national and global level (Korten 1990:121). The third generation argues that ordinary people cannot enjoy the dividends of development unless newly formed policies include development from the local level. Nevertheless, this process is long and slow because it takes time to achieve the necessary transformation of the institutions.

The fourth generation is a strategy of development that emerged with the realisation that the second and third generations could not distribute power and wealth proportional to the local, national and international levels (Korten 1990:123). The central concern of the fourth generation is to decentralise the distribution of wealth and power and to feed the people's initiatives. Therefore there is a need to keep people together, to mobilise and take control of their business through the power of ideas, values and communication links. In fact, despite all the criticism of the fourth generation such as that it results in insufficient mobilisation (Korten 1990:127), the principle and practice of this strategy still aimed at the appreciation of people's capacity and ability without domination of others (Yoms 2013:56). This awareness motivates the movement to people-centred development (Korten 1990:128). In the people-centred development approach the micro situation emphasises the development of communities rather than nations - it works with the particular rather than the general or universal (Speckman 2007:35). In this case local communities are involved at all levels of the development process.

This brings us to the URCSA's church structures and her involvement in the socio-economic context of South Africa. In various research contributions ${ }^{7}$ and reports on the URCSA's poverty alleviation involvement in the South African context is it apparent that the URCSA is involved in different projects in alleviating poverty. Yet, compared to Korten's aforementioned argument, the URCSA is still predominantly involved with first generation activities and struggles to move beyond a charity ('hand-outs') mode of intervention. Also since 1924, the early years of the DRMC up until this very day, the church is busy with first generation approaches (cf. Erasmus 2012:247; cf. Plaatjies van Huffel 2003:198). Although Badisa, a NGO/FBO of the URCSA and the DRC, is striving to move from welfare to developmental involve-

7 cf. Beukes 2014:155-167; cf. Report of the Economic Justice Working Group to the URCSA's Fifth General Synod 2008; Plaatjies van Huffel 2003; Erasmus 2012; Bowers du Toit 2012:257-268. 
ment, congregants of local congregations are reluctant to be involved in community development, as a structure such as Badisa is involved on their behalf. As long as congregants give their donation to Badisa the battle according to them is won. This narrow-minded understanding of changing and transforming communities makes it difficult for the church to move beyond Korten's first generation.

Bowers du Toit (2012:264-265) confirms this concern about the involvement of the URCSA based on the WRIGP project. The WRIGP project was a case study that was done in Paarl with local congregations in which five URCSA congregations participated. Bowers du Toit raised the fact that "love of neighbour" remains a pertinent theme in the context of the socio-economic restoration and reconciliation that still needs to take place in South Africa. However, she warns that if this theological theme is merely used as the "simplest" or "easiest" scriptural reference to theological motivation in social welfare, it loses its potency and may simply mean charity that may create dependence. Bowers du Toit based this warning on the fact that the majority of welfare work done by congregations in Paarl is largely relief work. She explains, "Soup kitchens, food parcels and the distribution of food and clothing - these actions might all be relevant in their contexts, but they still focus more on the symptoms than the causes of poverty and other social problems" (Bowers du Toit 2012:265).

However, this is not the only concern of the URCSA's involvement in social welfare when working on local congregational level. In our opinion Bowers du Toit (2012:265) highlighted a greater concern emanating from the Paarl case study which suggests that the theological theme of "God of the Poor" does not appear to be appreciated by current church leadership. This raises the question as to the seriousness and the embodiment of the Belhar Confession in URCSA circles. Although the greatest critique against these conclusions might be that five URCSA congregations in Paarl do not represent the URCSA in general, it still gives an indication whether the Belhar Confession is the motivation to combat poverty, socio-economic challenges and all forms of injustices. Furthermore, it also confirms that the mode of involvement is predominantly charity driven.

For the URCSA to be involved and relevant in this ongoing changing and changed socio-economic context of South Africa the church needs to use all her structures in order to embody the Belhar Confession and integrate it with Korten's Generation theories. On local congregational level it is still necessary to do charity (Generation 1 - Relief and Welfare) as the immediate need must be addressed. However, this must be done in conjunction with the other three generations. Presbyteries and or congregations clustered in the same areas focus on Generation two (Community development) mode of interventions while on Regional Synod level and General Synod level the foci are on Generation three (Sustainable systems development) and Generation four (People's Movement) modes of intervention. 


\section{URCSA and a theology of development}

The church's mission must be based in the contextual realities of specific people by meeting their needs (Bosch 1991:113-117). By starting to meet people's needs, it is possible to develop a relationship of trust that enables the church therefore to move to deeper issues of development. The church as both a theological and sociological reality has an important role to play in society.

Although in practice the church is still one of the most devided institutions, the church - especially URCSA with her Belhar Confession should remain central in terms of the idea of reconciliation and building of relationships. When people are reconciled with God and to each other, it becomes easier to love and care for each other. The ministry of the Mainline Missionary churches is primarily concerned with the individual's relationship with Jesus Christ and her missions and outreach to people with mental or physical needs outside the believing community (Sider 1999:138). Alston says that the ministry of the church is an active service to God with man in obedience to Jesus Christ. It is in the ministry to God in which people are served, and in the ministry to people in which God is served (Alston 2002:107). The church is a sign of the values of the kingdom such as: freedom, equality, justice, peace, hope and participation.

Furthermore, the church in development is also to establish cordial relations between people in the community. Myers is convinced that the common message of the church should be that people should live in peace with God and one another. Then the idea of exploitation and oppression will be minimal (Myers 2011:180183). When people are reconciled with God and each other, new relationships are established. The converted sinners obtain freedom to engage in cross-cultural, cross-political and cross-economic relations without discrimination.

Therefore, the church has the responsibility to fight for the rights of the people who are refused participation in society as a result of culture and origin. Furthermore, church involvement that entails poverty alleviation and development approaches that entail spiritual transformation must aim to free people from destructive attitudes, destructive beliefs, destructive values and destructive patterns of culture. In other words, the development work in Christian perspective is not only for eternal salvation, but also for the transformation of cultural and economic life (Olasky 1988:145).

If URCSA wants to be faithful to her confessional doctrine with regards to the Confession of Belhar, she cannot afford to ignore her public role in the world. The church must therefore be or create the space and platforms where the poor and those already silenced and rejected can speak for themselves. Justice, peace and equality are biblical claims that the church should not dare to ignore or forget (Koopman 2007:298). With regard to the government, the church should not accept any kind of administra- 
tive system that oppresses the masses of the churches. Rather, the church must express herself critically and work prudently with the government in honest partnership, not only on the formation of public opinion through inclusive public debate, but also in the formulation and implementation of public policies on behalf of the voiceless, the most disadvantaged and vulnerable in society. After all, the primary solidarity of the church does not lie with the government as such, but with the poor, the deprived and the vulnerable (Koopman 2007:299). However, August (2009:29) also warns that the church should not only concentrate on her spiritual role, but because of her own nature and calling, the church should not leave the political arena entirely in the hands of the state. This approach of the church should be seen as complementary to the people-centred social development paradigm. This means that the Christian approach does not disregard the development principle of participation, empowerment and sustainability. To be an agent of change the church should indeed act in unity with the community and participate in her life experience because the community understands their needs better than outsiders (August 2010:50).

In the process, the church must remain resolute in defence of the poor, oppressed and underprivileged. In this way the church will remain faithful to the biblical concept, but more specifically, the URCSA with the Belhar Confession as basis, will be required to embody Article 4 of the Belhar Confession as leaders in the fight against all injustices.

\section{Article 4 as motivation for moving towards a theology of development within the URCSA}

Consequently, a theology of development is theologically motivated in this section of the paper and is grounded as follows in Article 4 of the Belhar Confession:

"We believe that God's own revelation has revealed God as the One who wishes to bring about justice and true peace between people ..."

From the Bible, God reveals Himself as the One whose work is perfect, and all His ways are just. He is the faithful God who does no wrong, He is fair and reliable. In God there is no injustice. Therefore He cannot tolerate or connive injustice. About Jesus, born in Bethlehem, the angels sang of peace on earth. That's what Jesus in his last teaching also teaches: "Peace I leave with you ...", and that's what Ephesians 2:14 confesses about the new humanity: "Christ is our peace ..." God wants to establish this justice and peace among mankind. Therefore God wants to achieve a creation order based on justice and peace when it comes to the management of human affairs (Myers 1999:29).

For this reason, De Beer (2008:179) believes that especially in dealing with poverty, the aspects of justice and reconciliation of Belhar strongly emerge. He argues that poverty cannot be addressed by the poor alone; it should be addressed collectively by the broader community and the believers of faith. 
"We believe that in a world full of injustice and enmity God is in a special way the God of the destitute, the poor and those who suffer injustice ..."

How can God achieve justice and peace in a world full of injustice and discord? By choosing right in situations of injustice! By changing enmity to peace and healing. Therefore, where people suffer or are poor because of injustice in systems and society, God is there with and for them in a special way. He executes justice for the oppressed and gives food to the hungry. He protects the strangers and help orphans and widows, but he frustrates the ways of the wicked. The church and the people of the Lord are called to learn to do good, to ensure that justice is done and to oppose oppressors. That God stands for what is just is a perspective that meets the Reformed heritage with its emphasis on God who rules over everything and everyone (Teks en Kommentaar 2006:13).

It is also important to note that God does not stand by the poor because they are poor or because he is in a class struggle in a special way the God of the working class. God stands in a situation of injustice with people who are suffering from this injustice because of his innermost being (cf. Tshaka 2005:253).

"... and calls the Church to imitate this ..."

This is a biblical demand made unequivocally in Article 4 that the church must stand where God stands (Boesak 2008:9). The church, as people in the service of God, as followers of Jesus, is called to materialise the grace year and recovery year. The church must testify against injustice and for justice. This includes reprimanding of people with power who determine their own interest against other people's fate, for the sake of their own advantage. The church must give support and practical assistance to people who are suffering - no matter what form this suffering takes and no matter who is suffering (Botha \& Naudé 2010:186).

The church cannot escape this calling of her (Smit 2012:194; cf. Boesak 2008). A church that endorses the Belhar Confession and a church which belongs to God are called to stand where God stands. It also means that the church will learn to discern when and how it needs to fight against injustices and to stand for justice (Smit 2012:194).

"... that God brings justice to the oppressed and gives bread to the hungry; that God frees those in prison and makes the blind see; that God succours the downtrodden, protects strangers, helps orphans and widows and thwarts the path of the ungodly; that for God pure and undefiled religion is to visit the orphans and the widows in their affliction ..."

This poignant description of how God stands for justice is nothing more than a succession of Bible passages. Here it is clear that God has a special soft spot for those whose rights are threatened, such as widows, orphans and strangers. The church has no option but to follow God in this same attitude.

"... that God seeks to teach the People of God to do what is good and to seek the right ..." 
The Belhar Confession was not only formulated with a hermeneutic "view from below", but is also existentially consistent with the experience of oppression and the oppressed and marginalised people themselves (Tshaka 2005:256). Herein lays precisely the experience of the church that she, from her own being, has no other option but to assist the oppressed and to seek justice. The church as an agent of change is taught by God and is called to be actively involved.

De Gruchy (2007:358 \& 363) shares the same view when he states as follows; "It takes the church as given, one social institution amongst many - albeit a very important one - and seeks to shift its resources, activities, and ideological power, to the side of the poor and the oppressed". "We are a divided Church precisely because not all the members of our Churches have taken sides against oppression. In other words not all Christians have united themselves with God 'who is always on the side of the oppressed'. There can be no abandoning of the public sphere". The people of God are now called to repentance and confession of sin in order for God to teach them to do as He does, as he stands for justice and peace.

"... that the Church must therefore stand by people who in any way suffer or are in need, which among other things means that the Church will witness and take up the fight against any form of injustice, so that justice may roll down like waters, and righteousness like an ever-flowing stream; that as God's possession the Church must stand where God stands, namely against injustice and with those who suffer injustice ..."

The church must make a choice to stand where God stands because He is the source of justice, in situations of injustice He stands with the victims. That is how God is praised in His greatness and that is how Jesus outlines His ministry in Luke 4. As followers of Jesus, as people in the service of God the church is called to stand with God.

"... and that the Church as made up of those who follow Christ must witness against all the powerful and privileged who selfishly seek their own interests and rule over others to their disadvantage."

The church must testify against injustice and for justice. The church must give support and practical assistance to people who are suffering - no matter what form this suffering adopts and it does not matter who it is that suffers. This includes a witness against people who selfishly seek their own interests and rule over others to their own benefit.

\section{Article 4 and a theology of development: theological comparisons}

The role of the URCSA in development is non-negotiable because of her biblical and confessional claims with specific reference to the Confession of Belhar and more specifically Article 4 thereof. It is for this reason that some theological 
comparisons of Article 4 with a theology of development are presented as follows in diagamm $2^{8}$.

In the light of the diagram above and the argument of this paper, we are convinced that the Belhar Confession can contribute profoundly to a renewed and constructive engagement and momentum in motivating a theology of development within URCSA.

At this point of the discussion on a theology of development and Article 4 of the Belhar Confession we propose that:

The URCSA should strive to tackle the structures within which poverty arises;

The Belhar Confession, especially Article 4, must be embodied and used in depth to establish a theology of development within the URCSA;

A theology of development deals inter alia with the empowerment of the oppressed and marginalised in poverty situations, exactly what the URCSA confesses in her Belhar Confession, and should be prioritised;

Article 4 indicates that God's own revelation has revealed God as the One who wishes to bring about justice and true peace between people; that in a world full of injustice and enmity God is in a special way the God of the destitute, the poor and those who suffer injustice and calls the Church to imitate this. The URCSA has no option but to follow God in this;

The church, given its good infrastructure and human resources, has enormous potential to play an effective role in development in the South African context both on generations one to four level according to David Korten's generation strategic NGO intervention approach;

The Confession of Belhar is an ecclesial theological response to the context of injustices in South Africa because of the theological content of the confession as well as the context in which it came into existence;

Currently there is still extensive poverty and socio-economic injustices in South Africa which call URCSA to wholeheartedly embody her confession of Belhar;

The Belhar Confession is about the triune God, who builds, protects and cares for His church through the Word and the Holy Spirit. The Belhar Confession makes a call for the unity of the church as the community of believers is built from all human races. The Belhar Confession confesses that the church is a reconciled community and that reconciliation at all levels of society is needed. The Belhar Confession confesses that God is in a special way the God of the poor and the deprived and that the Church is called to meet the needs of the people;

A church that endorses the Belhar Confession will fight against any forms of injustice.

8 This diagram illustrates only a few important comparisons from the text of Article 4 of the Belhar Confession which motivate a theology of Development. 


\begin{tabular}{|c|c|}
\hline $\begin{array}{l}\text { Article } 4 \text { of the Belhar } \\
\text { Confession confesses }\end{array}$ & $\begin{array}{l}\text { A theology of } \\
\text { development implies }\end{array}$ \\
\hline $\begin{array}{l}\text { That God wants to teach His people to do good and to } \\
\text { seek justice }\end{array}$ & $\begin{array}{l}\text { That God is actively working in the world to materialise } \\
\text { its goals. For this reason God is deeply involved in the } \\
\text { work of the church in this world and even in transforma- } \\
\text { tive devel-opment (cf. Myers 1999:20). }\end{array}$ \\
\hline $\begin{array}{l}\text { That the Church will witness and take up the fight against } \\
\text { any form of injustice, so that justice may roll down like } \\
\text { waters, and righteous-ness like an ever-flowing stream. }\end{array}$ & $\begin{array}{l}\text { That the church is creatively and wholeheartedly in- } \\
\text { volved in the challenges and problems in the world (cf. } \\
\text { Dunne 1969: i). }\end{array}$ \\
\hline $\begin{array}{l}\text { That the Church must therefore stand by peo-ple who in } \\
\text { any way suffer or are in need. }\end{array}$ & $\begin{array}{l}\text { That the focus is on people (people-centeredness) (cf. } \\
\text { Korten 1990:115-123; Speckman 2007:35 and Yoms } \\
\text { 2013). }\end{array}$ \\
\hline $\begin{array}{l}\text { That God brings justice to the oppressed and gives bread } \\
\text { to the hungry; that God frees those in prison and makes } \\
\text { the blind see; that God succours the downtrodden, pro- } \\
\text { tects strangers, helps orphans and widows and thwarts } \\
\text { the path of the ungodly; that for God pure and un-defiled } \\
\text { religion is to visit the orphans and the widows in their } \\
\text { affliction. }\end{array}$ & $\begin{array}{l}\text { That the church is empowered to play an effective role } \\
\text { in development (cf. August 2010:50; Swart 2006:3 and } \\
\text { Korten 1990:118). }\end{array}$ \\
\hline $\begin{array}{l}\text { That the church of God believes that God's own revela- } \\
\text { tion has revealed God as the One who wishes to bring } \\
\text { about justice and true peace between people. }\end{array}$ & $\begin{array}{l}\text { That an approach that God's restoration of the world is } \\
\text { paramount (cf. Myers 1999:42). }\end{array}$ \\
\hline $\begin{array}{l}\text { That as God's possession the Church must stand where } \\
\text { God stands, namely against injus-tice and with those } \\
\text { who suffer injustice. }\end{array}$ & $\begin{array}{l}\text { That a preferential option is made to stand just like } \\
\text { God, with the poor, the needy and deprived (cf. Swart } \\
2010: 211 \text { ). }\end{array}$ \\
\hline $\begin{array}{l}\text { That the Church as made up of those who fol-low Christ } \\
\text { must witness against all the powerful and privileged who } \\
\text { selfishly seek their own interests and rule over others to } \\
\text { their dis-advantage. }\end{array}$ & $\begin{array}{l}\text { That the church should empower the insiders as well as } \\
\text { outsiders of the faith community to address all forms of } \\
\text { injustices (cf. Jenkins 1969:53). }\end{array}$ \\
\hline $\begin{array}{l}\text { That in a world full of injustice and enmity God is in a } \\
\text { special way the God of the destitute, the poor and those } \\
\text { who suffer injustice and calls the Church to imitate this. }\end{array}$ & $\begin{array}{l}\text { That Christ's hope and love to the destitute, the poor } \\
\text { and wronged regardless of race, cul-ture or background } \\
\text { is demonstrated (cf. Moltmann 1969:96). }\end{array}$ \\
\hline
\end{tabular}

Diagram 2: theological comparisons of article 4 and a theology of development

\section{Conclusion}

Following the aforementioned arguments, we suggest that, in light of its historical calling and identity, in her quest to tackle the problem of poverty and injustices among its members effectively, the URCSA is called to take Article 4 of the Belhar Confession as an anewed fundamental starting point. Article 4 motivates the URCSA in a new way to be involved in a theology of development with the aim to empower her effectively in her strategic actions to tackle poverty. A theology of development acknowledges the power of the powerless and can make a special contribution in respect of the concern that was raised at the URCSA's 2012 General Synod in Okahandja where it was realised and tabled that the URCSA's voice became quiet 
(the big silence) despite various injustices that currently occur in South Africa. ${ }^{9}$ Therefore, this article encourages and motivates the URCSA to wholeheartedly embrace the idea of moving beyond an "only charity mode" towards a theology of development.

\section{Bibliography}

Abrecht, P. \& Land, P. 1969. Common Christian convictions about development. In Munby, D. (ed.), World development: Challenge to the churches, 137-146. Washington, DC: Corpus Books.

Acta Synodi. 2012. Sixth General Synod of the Uniting Reformed Church in Southern Africa. URCSA

Alston, W.M. Jr. 2002. The church of the living God: A Reformed perspective. Louisville, KY: Westminster John Knox.

Alszeghy, Z. \& Flick, M. 1971. Theology of development: A quest of method. In Land, P. (ed.), Theology meets progress: Human implications of development, 105-143. Rome: Gregorian University Press.

August, K.T. 2010. Equipping the saints: God's measure for development. Bellville: The Print-Man.

August, K.T. 2009. The quest for being public church: The South African challenge to the Moravian Church in context. Bellville: The Print-Man.

Beukes, J.W. 2014. 'n Prakties-Teologiese Besinning oor die Betekenis van Artikel 4 van die Belydenis van Belhar as Grondslag vir die Vestiging van 'n Teologie van Ontwikkeling in die Verenigende Gereformeerde Kerk in Suider-Afrika (VGKSA). Ongepubliseerde PhD-Tesis: Universiteit van Stellenbosch.

Boesak, A. 2008. To stand where God stands: Reflections on the Confession of Belhar after 25 years. Stellenbosch: Beyers Naudé Centre for Public Theology.

Bosch, D.J. 1991. Transforming mission: Paradigm shifts in theology of mission. Maryknoll, NY: Orbis.

Botha, J.G. \& Naudé, P.J 2010. Goeie nuus om te bely: Die Belydenis van Belhar en die pad van aanvaarding. Wellington: Bybel-Media.

Bowers du Toit, N.F. 2012. Theology and the social welfare practice of the church: Exploring the relationship in the Paarl context. In Swart, I., Gouws., Pettersson., Erasmus, J. \& Bosman, F. (eds), Welfare, religion and gender in post apartheid South Africa: Constructing a South-North dialogue, 257-268. Stellenbosch: Sun Press.

De Beer, J.M. 2008. Die missionêre waarde van die Belhar-Belydenis vir die NG Kerk: Instrument tot eenwording. D-Phil Tesis. Universiteit van Pretoria.

De Gruchy, S.M. 2001. Guest editorial. Journal of Theology for Southern Africa 110 (July 2001):1-4.

De Gruchy, S.M. 2007. On not abandoning church theology: Dirk Smit on church and politics. NGTT 48(1), 356-365.

9 cf. Acta Synodi 2012:28 
Dickinson, R.D.N. 1991. Development, in Lossky, N., Bonino, J.M. \& Pobee, J. (eds.), Dictionary of the Ecumenical Movement, 268-274, Geneva: WCC Publications.

Dunne, G.H. (ed.). 1969. In search of a theology of development. Geneva Sodepax Report. Geneva: Committee on Society, Development and Peace (The Ecumenical Centre), WCC Publications.

Erasmus, J. 2012. Double legacy: Perceptions of churches as welfare agents in the new South Africa. In Swart, I., Gouws, A., Pettersson, P., Erasmus, J. \& Bosman, F. (eds.), Welfare, religion and gender in post-apartheid South Africa: Constructing a South-North dialogue, 241-256. Stellenbosch: Sun Press.

Gern, W. 1999. Christian development services. In Fahlbusch, E. et al. (eds.), The Encyclopedia of Christianity, 441-442. Grand Rapids, MI: Eerdmans.

Jenkins, D. 1969. The power of the powerless. In Dunne, G.H. (ed.), In search of a theology of development, 51-53. Geneva: Sodepax Report.

Klaasen, J. 2013. The interplay between theology and development: How theology can be related to development in post-modern society. Missionalia 41:2. Pp. 182-194.

Koopman, N. 2007. Reformed theology in South Africa: Black? Liberating? Public? Journal of Reformed Theology, 1(3), 294-306.

Korten, D.C. 1990. Getting to the 21st century: Voluntary action and the global agenda. West Hartford: Kumarian Press.

Kritzinger, J.N.J. 2010. Celebrating communal authorship: The Theological Declaration of the Belydende Kring (1979) and the Belhar Confession. In honour of Simon Maimela and in memory of Chris Loff. Studia Historiae Ecclesiasticae, 36, 209-231.

Modise, L. 2013. The Rocky Road Travelled by the Dutch Reformed Church in Africa Towards Church Unity: From Tshilidzini to Pretoria, 1971 to 1991. NGTT Deel 54, Nommers 3 \& 4, September \& Desember 2013. Online Available - accessed on 21 March 2015

Moltmann, J. 1969. The Christian theology of hope and its bearing on development. In Dunne, G.H. (ed.), In search of a theology of development, 93-100. Geneva: Sodepax Report.

Myers, B.L. 2011. Walking with the poor: Principles and practices of transformational development. (3rd ed). Maryknoll, NY: Orbis.

Myers, B.L. 1999. Walking with the poor: Principles and practices of transformational development. Maryknoll, NY: Orbis.

Naudé, P.J 2010. Neither calender nor clock: Perspectives on the Belhar Confession. Grand Rapids, MI: Eerdmans.

Offutt, S. 2012. New directions in transformational development. The Asbury Journal $67(2): 35-50$.

Olasky, M. 1988. The Villars statement on relief and development. In Schlossberg, H. \& Clark, H.P. (eds.), Freedom, justice, and hope: Toward a strategy for the poor and the oppressed, 141-146. Westchester: Crossway.

Plaatjies Van Huffel, M.-A. 2013a. The Belhar Confession: Born in the struggle against apartheid in Southern Africa. Studia Historiae Ecclesiasticae, 39(1), 185-203.

Plaatjies Van Huffel, M.-A. 2013b. Reading the Belhar Confession as a historical text. In Plaatjies-Van Huffel, M.A. \& Vosloo R.R. (eds.), Reformed churches in South Africa and the struggle for justice, 329-345. Stellenbosch: Sun Press. 
Plaatjies Van Huffel, M.-A. 2003. Vroue in die teologiese antropologie in die Afrikaanse Gereformeerde tradisie. Ongepubliseerde DTh-tesis. Pretoria: University of South Africa.

Rendtorff, T. 1969. A theology of development? In search of a theology of development. Papers from a Consultation on Theology and Development held by Sodepax in Cartigny, Switzerland, November 1969, 204-217. Geneva: Sodepax.

Report of the Economic Justice Working Group to the URCSA's Fifth General Synod 2008, at Hammanskraal 29 September - 5 Oktober 2008.

Reynolds, A. \& Offutt, S. 2014. Global poverty and evangelical action, in Steensland, B. \& Goff, P. (eds.), The New Evangelical Social Engagement, 242-261, Oxford: Oxford University Press.

Samuel, V. 1996. The development movement: An overview and appraisal. Transformation (December 1996). Pp.12-16.

Sider, R.J. 1999. Good news and good works: A theology for the whole gospel. Grand Rapids, MI: Baker.

Smit, D.J. 2012. Oor die teologiese inhoud van die Belydenis van Belhar. Acta Theologica, 32(2), 184-202.

Smit D.J. 2006a. Die Gereformeerde siening van belydenis? Enkele algemene gedagtes. [Aanlyn: http://www.ngkok.co.za/KonventAlgemeen/OpmerkingsOorBelydenis_ Smit DJ_2006.pdf - 10 Julie 2008.

Smit, D.J. 2006b. Barmen and Belhar in conversation - a South African perspective. Nederduitse Gereformeerde Teologiese Tydskrif, 47(1/2), 291-301.

Speckman, M.T. 2007. A Biblical vision for Africa's development. Pietermaritzburg: Cluster.

Strauss, P.J. 2004. Die teologiese en morele regverdiging van apartheid en 'n "status confessionis". 'n Vergelyking tussen die Wêreldbond van Gereformeerde Kerke en die Gereformeerde Ekumeniese Sinode se hantering van die saak. Acta Theologica Supplementum 6, 96-121.

Swart, I. 2012. Welfare, religion and gender in post-apartheid South Africa: Constructing a South-North dialogue. Stellenbosch: Sun Press.

Swart, I. 2010. The third public: Hermeneutical key to the theological debate on church and development? in Swart, I., Rocher, H., Green, S. \& Erasmus, J. (eds.), Religion and social development in post-apartheid South Africa: Perspectives for critical engagement, 205-224. Stellenbosch: Sun Press.

Swart, I. 2008a. Meeting the challenge of poverty and exclusion: The emerging field of development research in South African practical theology. International Journal of practical Theology 12(1):104-149.

Swart, I. 2008b. Market economy development, local economic experience and the Christian movement towards alternatives in a South African city region. In De Gruchy, S., Koopman, N. \& Strijbos, S. (eds.), From our side: Emerging perspectives in development and ethics. Leiden Brill.

Swart, I. 2006. Transforming social welfare? The religious discourse on social development in post-apartheid South Africa. Paper presented at the First Conference of the SouthAfrican Swedish-Research Links Project, "Welfare and religion in a global perspective: 
Theoretical and methodological exchange across the North-South divide (WRIGP), Stellenbosch, 6-8 Dec 2006.

Teks en Kommentaar 2006. Belydenis van Belhar 1986: Teks en Kommentaar. 'n Publikasie van die Konvent vir Eenheid Kaapland 2006.

Thomas, D. 2002. Christ Divided: Liberation, Ecumenism and Race in South Africa. Pretoria: Unisa Press.

Tshaka, R.S. 2005. Confessional Theology? A Critical Analysis of the Theology of Karl Barth and its Significance for the Belhar Confession. Unpublished DTh Thesis, Stellenbosch: University of Stellenbosch.

Yoms, E. 2013. Towards a people-centred approach in theology for socio-economic rural community development in Nasarawa State, Nigeria. MTh Thesis, University of Stellenbosch. 